\title{
The Bush Doctrine:
}

A Critical Appraisal

Heajeong Lee

(Chung-Ang University)

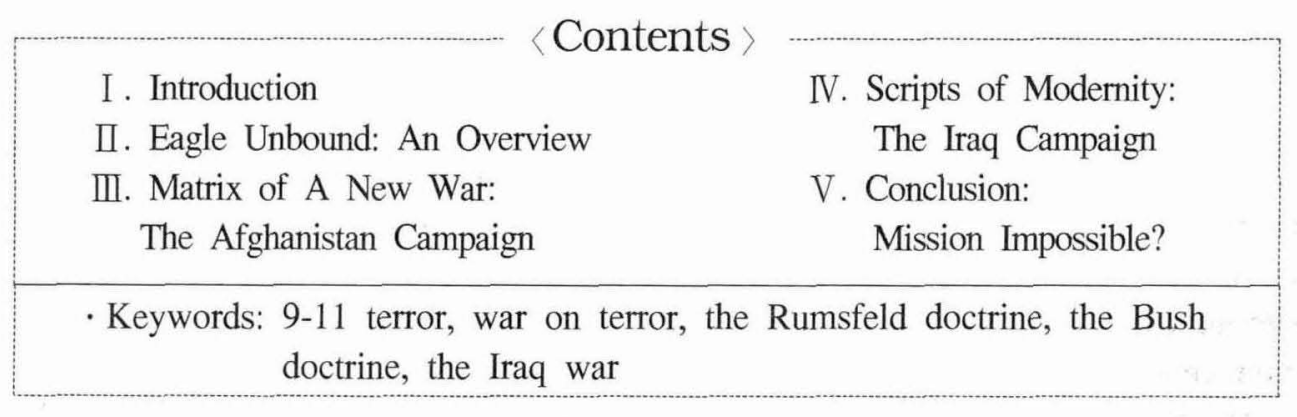

\section{【 ABSTRACT 】}

This paper attempts to critically examine the strategic and moral rationale of the Bush doctrine that has guided America's war on terror. Premised upon the efficacy of America's military power and self-righteousness, the Bush doctrine has moralized the very concept of security and extended the spatial and time dimensions of American security strategy. Unbound with the traditional strategic and moral diffidence, the Bush doctrine has embraced preventive war and regime change; this strategic over-reach has guided America's war in Iraq and resulted in international frictions on the terms of America's war on terror and American leadership in general. 


\section{I . Introduction}

On 11 September 2001, the al Qaeda terrorist attacks on the United States exacted more than 3,000 innocent lives- Americans and citizens of more than 60 nations. The 9-11 terrorist attacks, the U.S. President George W. Bush condemned on the same day, were "the despicable, evil acts of terror."1) On the next day, Bush called the 9-11 attacks more than "acts of terror": "They were acts of war."2) On September 20, Bush declared "war on terror" that "will not end until every terrorist group of global reach has been found, stopped and defeated." 3 )

The Bush doctrine has guided and moralized America's war on terror, subjecting terror not to the traditional confines of police action but to America's awesome military power and thereby dictating changes in the traditional terms of war and diplomacy. In particular, the Bush doctrine allowed no neutrality in the "first war of the 21st century": "Every nation, in every region, now has a decision to make. Either you are with us, or you are with the terrorists. From this day forward, any nation that continues to harbor or support terrorism will be regarded by the United States as a hostile regime."4)

The purpose of this paper is to examine the Bush doctrine and its impacts on world politics. This paper is premised upon that security strategies are not just reactions to events of security threats. Though events themselves are not constructed, the interpretations of and responses to events are constructed by particular perceptions of intentions, interests and historical conditions. America is a prototype of a "constructed nation."5) No American security strategy has been immune from some reflections on America's long and entrenched self-identity-American exceptionalism. Moreover, the 9-11 terrorist attacks marked an unprecedented event in a historical flux that had no fixed primer of interpretation. The terrorist attacks are still called just by the number of 9-11, and which means that the attacks are subject to various interpretations and responses. Therefore, it is necessary not to reify America's official line of interpretations of 9-11 and responses thereupon. A full appreciation of the Bush doctrine requires an analytical, ideological, and historical distance, which this paper tries to get by canvassing a wide range of sources - the primary texts of American security policy makers and the works of not just security specialists but also legal scholars and diplomatic historians. Beginning with an overview of the development of the Bush doctrine, this paper tries to detail its strategic and moralistic rationale and their implications on the terms of war and peace: the former will focus on the Afghanistan campaign and the latter on the Iraq campaign.

1) George W. Bush, "Address to the Nation," September 11 (2001a).

2) Bush, "Remarks by the President in Photo Opportunity with the National Security," September 12 (2001b)

3) Bush, "Address to a Joint Session of Congress and the American People," September 20 (2001c)

4) Bush (2001c).

5) James Kurth,. "America's Grand Strategy: A Pattern of History," The National Interest 43(1996), pp 3-19. 


\section{П. Eagle Unbound: An Overview}

In October 2001, the Taliban regime refused America's demand to surrender Osama bin Laden and all the al Qaeda terrorists, and Afghanistan became the first major battlefield of the U.S.-led global war on terror. In the Afghanistan campaign, Bush's imposition of "great divide of our own time not between religions or cultures, but between civilization and barbarism" was backed up with both the U.N. Security Council's endorsement and the American military's RMA (Revolution in Military Affairs)-based "new way of war."6) By the beginning of 2002, the Taliban regime was toppled and the U.S. began the reconstruction and nation-building of Afghanistan, once "the graveyard of empires."7)

The victory of the Afghanistan campaign buoyed the morale of the Americans, if not all Americans but certainly of Bush himself. "Now America is embracing a new ethic and a new creed," Bush exalted in his 2002 state of union address, "Let's roll." Now the divide between civilization and barbarism was focused on the "axis of evil" of North Korea, Iran, and Iraq, which had sponsored terror and developed weapons of mass destruction. ${ }^{8)}$ Sadam Hussein's Iraq was picked up as the next target of America's war on terror. In fact, the U.S. defense secretary Donald Rumsfeld had argued for war against Iraq as immediately as on the next morning of the 9-11 terrorist attacks.9) Bush's "axis of evil" speech was a public opening salvo to America's Iraq campaign. In February 2003, Bush repeated a slogan of crusade for the very "civilization" of the world: "In Iraq, a dictator is building and hiding weapons that could enable him to dominate the Middle East and intimidate the civilized world- and, we will not allow it." 10 )

While readying a global coalition and the American military to roll over Iraq more than a year, the Bush doctrine was partaking of a full-fledged moral crusade and unilateralism. In his graduation speech at the West Point on June 1, 2002, Bush emphasized a new strategic doctrine of preemption, burying America's cold war strategies of containment and deterrence: "We must take the battle to the enemy, disrupt his plans, and confront the worst threats before they emerge. In the world we entered, the only path to safety is the path of action. And this nation will act." For Bush, "Our nation's cause has always been larger than our nation's defense." And America, armed with unrivaled military prowess, now should seize a historic chance and responsibility to build "a just and peaceful world beyond the war on terror."11)

Bush's West Point speech was carried into the National Security Strategy of September 2002. The document crystallized and sanctified an unabashed American unilateralism with

6) Bush, "We're Fighting to Win And Win We Will," December 7(2001d); Max Boot, "The New American Way of War," Foreign Affairs 82-4(2003), pp. 41-58.

7) Milton Bearden, "Afghanistan, Graveyard of Empires," Foreign Affairs 80-6 (2001), pp.17-30.

8) Bush, "State of Union Address," January 28 (2002a).

9) Perry Anderson, "Force and Consent," New Left Review 17 (2002), pp. 5-30.

10) Bush, "President Discusses the Future of Iraq," February 26 (2003a).

11) Bush, "Graduation Speech at West Point," June 1 (2002b). 
America's self-righteousness: "America is not just a stronger, but is freer and more just society." Within a year after the 9-11 terrorist attacks, the Bush administration completely discarded America's traditional strategic guides and set out a clean slate for a new American century. Now preemption would override deterrence, global coalition against terror over traditional alliances, American sovereignty and freedom of action over international regimes. Most of all, America is now freed from prudence or self-restraint of the use of power that even Reagan's foreign policy, albeit its hyperbolic ideological rhetoric, had abided by. ${ }^{12)}$ Bush's internationalism builds on "the union of our values and our national interests," and the first task of American foreign policy is to "champion aspirations for human dignity."13) Dismissing realism's prudence and conservatism's skepticism on moral certitude, America's new conservatism now wholeheartedly embraces Wilsonianism, in particular the project of democratic nation-building. Embodying "Wilsonianism on the Right," Bush let American foreign policy unbound with any skepticism about American morality and power in the Iraq campaign. ${ }^{14)}$

Indeed, the American military rolled over the Sadam Hussein regime, even dispensing with the U.N. Security Council's endorsement and without substantial supports from the international community. However, the Bush administration has not (yet) found out Iraq's weapons of mass destruction that had been sorted out as an immediate threat to the U.S. security and the world of civilization; nor a clear link between the Sadam Hussein regime and international terrorism has been evidenced. Most of all, nation-building in Iraq has not fared well. The U.S. causalities amounted after the fall of Baghdad and there arose neither a clear blueprint for Iraqi democratization nor a new democratic Iraqi political leadership. Amid mounting skepticism on prospects for democracy in Iraq and the Middle East in general, the Bush administration is now rallying for the Americans' belief in "the the battle of ideas."15) "We go forward with confidence," Bush prides Americans in November 2003, "because we trust in the power of human freedom to change lives and nations. By the resolve and purpose of America, and of our friends and allies, we will make this an age of progress and liberty."16)

\section{Matrix of A New War: The Afghanistan Campaign}

The 9-11 terrorist attacks did not dictate America's war on terror, and the latter of which defied a clear and quick definition. Sure, the 9-11 terrorist attacks themselves were

12) Immanuel Wallerstein, "The Eagle Has Crash Landed," Foreign Policy 131, pp. 60-68; John Lewis Gaddis, "A Grand Strategy," Foreign Policy 133(2002), pp. 50-57.

13) The White House, The National Security Strategy of the United States of America (2002).

14) Joseph S. Nye, "U.S. Power and Strategy After Iraq," Foreign Affairs 82-4(2003), pp. 60-74.

15) Douglas J Feith, "Strategy and the Idea of Freedom," November 24(2003); Paul Wolfowitz, "Winning the Battle of Ideas: Another Front in the War on Terror," October 30 (2003).

16) Bush, "Text: Bush on Democracy in the Middle East," November 7, The New York Times(2003e). 
unprecedented and far beyond the confines of traditional terrorist attacks, in terms of their diabolically methodical execution of synchronized attacks and the resultant scale of destruction. Most of all, the 9-11 attacks vindicated the vulnerability of the American homeland and were instantly allured to the Pearl Harbor in 1941. The surprise, fear, grief, and anger at "Ground Zero" were to call for a new way of the American homeland security and some sorts of America's military responses. 17)

In fact, the previous American administrations had attacked terrorists; most recently, in 1998, the Clinton administration bombed Sudan and Afghanistan against the very al Qaeda. However, the previous American administrations had not declared war against terrorist attacks. And, hypothetically speaking at least, the 9-11 terrorist attacks could have been responded other than the Bush administration's war on terror, whose duration is virtually indefinite and goals have continually expanded, and whose method has relied heavily on the RMA-driven transformation of the American military at the expanse of other counter-terrorism measures such as diplomacy and intelligence. ${ }^{18)}$

For instance, Mueller issues an extreme case against the Bush administration's war on terror. He argues that the 9-11 terrorist attacks could be a case of an outlier or a historical aberrant, which would not happen again and should not dictate a sweeping change in American security strategy. "A vastly exaggerated U.S. global military response to September 11," he warns, "could inadvertently produce enough fear and resentment abroad to increase the possibility of this happening." 19 )

Terror has traditionally belonged to the realm of national civil laws, subject to the law enforcement of police and, by extent, to the zone of peace. War has been a preserve for sovereign states and a vital mechanism of international security. The international laws do not prohibit war among states that have the monopoly of legitimate force. Rather the laws of war circumscribe the right to resort to war (jus ad bellum) and the actual use of force in war (jus in bello). While the international security or war paradigm is basically proactive and permissive, the law enforcement paradigm is reactive and prohibitive. For instance, the presumption of innocence until proven guilty applies to terrorists as criminals but not to combatants. ${ }^{20)}$

17) Ashton B. Carter, "The Architect of Government in the Face of Terrorism," International Security 26-3(2001/2002), pp. 5-23; Stephen E. Flynn, "America the Vulnerable," Foreign Affairs 81-1 (2002), pp. 60-74; Richard Betts, "The Soft Underbelly of American Primacy: Tactical Advantages of Terror," Political Science Quarterly 117-1(2002), pp. 19-36.

18) Donald Rumsfeld, "Transforming the Military," Foreign Affairs 81-3 (2002), pp. 20-32; Philip B. Heymann, "Dealing with Terrorism: An Overview," International Security 26-3 (2001/2002), pp. 24-38; Verna V. Gehring (ed.), War After September 11 (New York: Rowman and Littlefield, 2003).

19) John Mueller, "Harbinger or Aberration? A 9/11 Provocation," The National Interest 69(2003), p. 50.

20) Ashton Carter and William Perry, Preventive Defense: A New Security Strategy for America (Washington, D.C.: Brookings Institution Press, 1999), chapter 5; Adam Roberts, "Counter-terrorism, Armed Forces and the Laws of War, Survival 44-1(2002), pp. 7-32; Neta C. Crawford, "Just War Theory and the U.S. Counterterror War," Perspectives on Politics 1-1(2003), 
To wage war against terror is to cross the traditional divide between war and peace, and which is to obfuscate the traditional definition and terms of war. On September 27, 2001, Rumsfeld gives a lecture to the Americans on what they should and should not expect from a coming war: "this will be a war like none other our nation has faced." The nature of a new war, Rumsfeld resigns to note, could be more easily defined "by talking about what it is not rather than what it is." America's new war is going to be waged not by traditional alliances but by "floating coalitions." The targets of this new war are "a global networks of terrorist organizations and their state sponsors." Terrorist networks are global, even non-territorial, and resilient. As such this war could not be over by invading and occupying a state's territory: "When we 'invade the enemy's territory,' we may well be invading his cyberspace." Rumsfeld alerts the Americans: "Forget about 'exit strategy"; we're looking at a sustained engagement that carries no deadlines"(italics added). He confesses "no fixed rules about how to deploy our troops" but promises to "establish guidelines," and assures the Americans that: "America remains indomitable."21)

"America indomitable" is the key to the matrix of America's new war, of which manual and guidelines are laid out in the Quadrennial Defense Review (QDR) of September 31, 2001. The QDR interprets the 9-11 attacks in a framework of "America indomitable" or "vulnerability of America invincible," which has been pointed out and wamed of by the American security experts. ${ }^{22)}$ The "vulnerability of America invincible" framework has recognized America's unrivaled military power after the Cold War but warned of America's vulnerability to new threats from non-state actors with unconventional weaponry in the name of asymmetrical threats and conflicts. The QDR transforms and elevates asymmetrical threats from a new type of threat to a new strategy that would not allow "asymmetrical advantages to opponents" by proactively "deter and defeat adversaries who will rely on surprise, deception, and asymmetrical warfare": "A central objective of the review was to shift the basis of defense planning from a 'threat-based' model that has dominated thinking in the past to a 'capabilities-based' model for the future."23)

The capability-based strategy is premised upon the certainty of the uncertain and surprising asymmetrical threats to America in the future. On October 4, 2001, the U.S. Deputy Secretary of Defense Paul Wolfowitz preaches before the Senate Armed Services Committee: "We must prepare ourselves for the virtual certainty that we will be surprised again." According to Wolfowitz, the certainty of surprise is destined by the combination of technological development (in particular information revolution) and globalization that not only develops and integrates free economies but also globalizes and arms America's new adversaries. In a stark contrast to Mueller's interpretation of the 9-11 terrorist attacks

pp. $5-25$.

21) Donald H. Rumsfeld, "A New Kind of War," The New York Times September 27 (2001).

22) Richard Betts, "The New Threat of Mass Destruction," Foreign Affairs 77-1(1998), pp. 26-41; Carter and Perry(1999); The United States Commission on National Security $/ 21^{\text {sf }}$ Century, "New World Coming: American Security in the $21^{\text {st }}$ Century" (1999).

23) The U.S. Department of Defense, Quadrennial Defense Review (2001), p. iv. 
as a historical aberrant, Wolfowitz argues that the certainly of surprise is evidenced by the 9-11 terrorist attacks: "Today's terrorist attack is a precursor of even greater threats to come."24) This doomsday scenario underpins the shift of America's geopolitical focus away from the Atlantic alliance. Two regions arise as the new foci of America's geopolitics in the QDR. One is "a broad arc of instability that stretches from the Middle East to Northeast Asia" - a region of political instability, fervent with various extremism, and weapons of mass destruction. The other is "the East Asian littoral from the Bay of Bengal to the Sea of Japan," where the future great powers (of China and India) might arise and the American military lacks accesses.25)

America's new and future adversaries are, Wolfowitz posits, "less likely to be discouraged by traditional deterrence" and share "a desire to see America driven into retreat and isolation." Therefore, America's security task in the wake of the 9-11 terrorist attacks is not merely to fight against terrorism but to prevent the rise of any challenges to American hegemony by denying adversaries" "access-denial" and by "dissuading" adversaries' very "incentive to compete." Such a task requires not only America's absolute security but also America's absolute offensive capability, which in turn requires the transformation of U.S. forces capabilities, and institutions to extend America's asymmetric advantages well into the future.26)

Rumsfeld believes in and takes his mission the transformation of the American military as the key to war on terror and to the preservation of American hegemony itself. Rumsfeld sets America's security challenge as "to defend our nation against the unknown, the uncertain, the unseen, and the unexpected," which "may seem an impossible task." But, he asserts that: "It is not." His solution lies in the abandonment of the traditional strategies of containment and deterrence, the transformation of the American military, and the adoption of a new way of war, all of which amount to an extreme form of American military unilateralism utilizing RMA and unhindered by any factors domestic, international, political, or fiscal, or whatsoever. For instance, he argues that: "No U.S. president should have to choose between protecting citizens at home and U.S. interests and forces overseas. We must be able to do both. The notion that we could transform while cutting budget was seductive, but false." His military unilateralism is most conspicuous in war on terror: "The mission must determine the coalition, the coalition must not determine the mission, or else the mission will be dumbed down to the lowest common denominator." $\mathrm{He}$ embraces prevention (a clear violation of just cause of war), without trying to obfuscating it with preemption (a just cause of war): "defending the United States requires prevention and sometimes preemption.The best - and, in some cases, the only defense is a good offense."27)

24) Wolfowitz, "Building a Military fore the $21^{\text {st }}$ Century," Testimony to the Senate Armed Services Committee, October 2 (2001).

25) The U.S. Department of Defense (2001), p. 4.

26) Wolfowitz(2001).

27) Rumsfeld (2002), p. 23, 28, 31. 
America's strategic rationale in the Afghanistan campaign is a "multi-layered" one. The Afghanistan campaign is much more than a mere act of retaliation against the al Qaeda's attacks on the American homeland. Afghanistan is at an important intersection of "a broad arc of instability" and the "East Asian littoral." This spatial strategic logic is inextricably intertwined with America's strategic matrix of time - "the certainty of surprise." Thus the time dimension of the Afghanistan campaign extends into the future. As the campaign's time dimension expands, so does its mission expand to the goal of preventing any challenge to American hegemony; so do the transformation of the American military become important. As a result, from America's military point of view, the Afghanistan campaign becomes a test ground for American military unilateralism, which is dubbed the Rumsfeld doctrine. In addition to this "multi-layered" strategic rationale, America's Afghanistan campaign is couched in a moral dimension of the Bush doctrine: the Taliban regime and al Qaeda, in general America's all adversaries, are demonized as evil, barbarian, and "heir to fascism."

This "multi-layered" matrix of America's new war is an open invitation of problems with the traditional terms of war and diplomacy. The moralization of the very mission of war on terror against barbarian has the potential to expense with just conducts in war (jus in bello): i.e., a just cause (end) of war could justify any use of force in war (means). This problem is, theoretically speaking, aggravated by the Rumsfeld doctrine on the priority of mission over coalition: in other words, America should have the right and power to define mission and other (civilized) nations have only the duty to cooperate with America. This is a formula for potential conflicts in coalition-building and multilateral diplomacy, and for America's temptation to obfuscate jus ad bellum with jus in bello. Moreover, the long time horizon of America's threat perception and multiple missions (including prevention) could undermine America's claim of self-defense as the legitimacy of war on terror. For the self to be protected is expanded too far in terms of time and interests America's homeland, overseas Americans, bases, allies and American hegemony itself in the future. ${ }^{28)}$

These problems relating to jus ad bellum and multilateral diplomacy were much muted in the Afghanistan campaign, because of the clear injury inflicted upon Americans and more than 60 other nationals by the 9-11 terrorist attacks. The Bush administration could make a convincing case for the right to retribution and self-defense. ${ }^{29)}$ NATO evocated a clause of collective security; the UN Security Council endorsed the Afghanistan campaign. Nonetheless, the Afghanistan campaign was plagued with many thorny questions. Most conspicuous was the issue of POW (Prisoners Of War). The U.S. has traditionally opposed to accord irregular armed forces - mainly, guerrillas and soldiers of national liberation movements - the status of lawful combatants. On the other hand, the

28) Crawford(2003); Michael Byers, "Letting the Exception Prove the Rule," Ethics \& International Affairs 17-1, pp. 9-16.

29) Jack M. Beard, "America's New War on Terror: The Case for Self-Defense Under International Law," Harvard Journal of Law and Public Policy 25-2(2002), pp. 559-590. 
international society in general has moved to accept military irregulars as lawful combatants in the 1977 Protocol I Additional to the 1949 Geneva Convention, which also stipulated a more stringent clause on protection from "collateral damage," and has been endorsed by America's major European allies, including Britain, Germany and France.30) The U.S. opposition has been for divesting the legitimacy of irregulars' political cause. It is no wonder that the Bush administration followed that tradition in a new war against barbarians. Thus, the American military treated the captured Taliban soldiers and al Qaeda terrorists as criminals not as POWs, which was to cause criticisms of America's "hybrid war-law approach" that put those captured combatants and suspects in a limbo of rightlessness. ${ }^{31)}$

America's "new way of war" was a main source of problems relating to laws of war in the Afghanistan campaign. Laws of war stipulate the protection of innocent non-combatants and the norm of proportionality that retaliation against combatants should be proportional to the injury inflicted. Even though the Bush administration officials repeatedly emphasized that America was not waging a war against the people of Afghanistan, America's way of war - heavily relying on high-altitude "smart" bombing - could not be sufficiently discriminatory to quell the criticisms concerning the norms of protection of the innocent from "collateral damage" and proportionality. The issue of proportionality was also raised as to the suppression of a prison camp riot at Mazar-e Sharif. Questioned on the proportionality of the incident, Rumsfeld confessed that: "Your question's too tough for me. I don't know what 'proportionate' would be." Faced with criticisms of America's indiscriminating bombing and resultant "collateral damage," Rumsfeld even argued that: "We did not start this war. So understand, responsibility for every single causality in this war, whether they're innocent Afghans or innocent Americans, rests at the feet of the al Qaeda and the Taliban."32)

These criticisms would continue to plague America's indefinite war on terror, given the traditional American military doctrine of employing "decisive forces" and the Bush administration's moral conviction and earnest pursuit of military transformation.

\section{Scripts of Modernity: The Iraq Campaign}

America's war on terror has three fronts: the American home front and the international front as the war's logistic and ideological background, and the theaters of actual fighting Afghanistan and Iraq as the major battlefields so far. In terms of America's official military operation, the Iraq campaign was a swift and decisive victory. Bush ordered the "Operation Iraqi Freedom" to begin on March 20 and declared its end on May 1, 2003. Splendidly

30) David R. Rivkin and Lee A. Casey, "Leasing the Dogs of War," The National Interest 73 (2003), pp. 57-69.

31) David Luban, "The War on Terrorism and the End of Human Rights," in Gehring (2003)

32) Quoted in Roberts(2002), p. 21, 10. 
staged on the USS Abraham Lincoln, Bush's Mary 1 speech celebrates the victory "for the cause of liberty, and the peace of the world and prides the American military's great power to free a nation by breaking a dangerous and aggressive regime with new tactics and precision weapons." He makes a tribute to America's traditional commitment to liberty "declared at our founding; affirmed in Franklin Roosevelt's Four Freedoms; asserted in the Truman Doctrine and in Ronald Reagan's challenge to an evil empire." For him, liberty provides "the surest strategy to undermine the appeal of terror in the world," buttressed by the American military "as last resort" and with the support of the international community: "We're working with a broad coalition of nations that understand the threat and our shared responsibility to meet it." While cautioning that victory is not an end of the war on terror and that Iraq's "transition from dictatorship to democracy will take time," Bush cheers for "a crucial advance in the campaign against terror" and a prospect for the latter's final victory: "Free nations will press on to victory." 33 )

Bush's cheers were not free from suspicion and criticism at that time, while Bush's cautions have proven more ominous thereafter. Even before the "Operation Iraqi Freedom," the Iraq campaign had not fared well in all the three fronts - American, international, and Iraq. In September 2002, the Bush administration stepped up a public relations campaign for war against Iraq, condemning Sadam Hussein's "deception and defiance" and pressing for action on both the American and international fronts. Specifically, Bush asked for an Iraqi war resolution from the U.S. Congress (on September 19) and from the U.N. Security Council (on September 12). Bush secured the former on October 11 but only after intense congressional debates and several rounds of his personal urgings, and never got the latter.

On November 8, 2002, the U.N. Security Council passed a resolution(1441) to criticize Iraq's "material breach" of past U.N resolutions on weapons of mass destruction but to call for another round of inspection. In early 2003, the U.N. inspection was underway in Iraq and the "axis of peace" of France, Germany, and Russia pledged to block an Iraqi war resolution by the "axis of war" of the U.S., Britain, and Spain. For Bush, the "total disarmament" of Iraq's weapons of mass destruction was the only condition that America would forego a war against the Sadam Hussein regime. Hussein was not doing that, which Bush claimed to know from American intelligence, on March 6, 2003: "Inspection teams do not need more time, or more personnel." Bush declared that the U.S. would go to war even without a war resolution from the U.N.: "Sadam Hussein and his weapons are a direct threat to this country, to our people, and to all free people. If the world fails to confront the threat posed by the Iraqi regime, refusing to use force, even as a last resort, free nations would assume immense and acceptable risks. The attacks of September the $11^{\text {th }}, 2001$ showed what the enemies of America did with four airplanes. We will not wait to see what terrorists or terrorist states could do with weapons of mass destruction."34)

Indeed, Bush dispensed with another U.S. Security Council resolution on Iraq and

33) Bush, "President Bush Announces Major Combat Operations in Iraq Have Ended," May 1 (2003c).

34) Bush (2003b). 
ordered the beginning of the "Operation Iraqi Freedom" on March 20, failing to convince "all free people" of his reasoning of the "certainty of surprise" - the 9-11 terrorist attacks as a testimony to "a direct threat" from Sadam Hussein's weapons of mass destruction. Thus America's global coalition for the Iraqi campaign was not so "broad" and not "all free people" agreed that the American military power was used as "the last resort." This disunity in the international front on the mission and the ways of war on terror has not been mended: Bush has so far failed to found Sadam Hussein's weapons of mass destruction. Neither has the American military with "new tactics and precision weapons" succeeded in securing the safety of American soldiers, not to mention building an independent and democratic Iraq: Iraqi resistance forces have exacted more American causalities after May 1 than during the "Operation Iraqi Freedom." In July 2003, a field research of the Center for Security and International Strategy concluded that: "There is no 'new way of war' without conflict termination, peacemaking, and nation building." 35 )

On September 7, 2003, Bush admitted America's troubles in Iraq but insisted that: "This undertaking is difficult and costly - yet worthy of our country, and critical to our security." A democratic Iraq would, he explains, work "as a great setback for international terrorism"; on the other hand, the failure of democratic nation building in Iraq would make the whole Middle East "as an exporter of violence and terror that takes more lives in America and in other free nations." According to him, the American military power could be an effective tool in democratic nation-building because the people, as opposed to the suppressing regimes, inherently long for democracy: "The terrorists thrive on the support of tyrants and the resentments of oppressed peoples. When tyrants fall, and resentment gives way to hope, men and women in every culture reject the ideologies of terror, and turn to the pursuits of peace. Everywhere that freedom takes hold, terror will retreat." In other words, once the American military power topples tyrants, like a surgeon who cuts off "evil" tumors from a patient's body, then democracy would follow automatically. And this reason's firm foundation is America's self-righteousness: "America are serving in freedom's cause - and that is the cause of all mankind."36)

Bush's reasoning amounts to what might be called a "Garden of Eden" for American exceptionalism where America, untainted by any evil and embodying justice, wields its mighty power for the whole world. This ideal world builds on a set of moralistic and simplistic constructions of the history of America and modernity itself, and which could not stand close historical scrutiny. For instance, the founding assumption of the Bush doctrine -- America as the embodiment of modernity and liberalism -- is blind to America's not-so-immaculate records of liberalism concerning the racial, ethnic minorities. ${ }^{37)}$ The Bush doctrine's dichotomy of civilization and barbarism ignores a vast area of "gray," including the Middle East, where America has been entangled with not-so-moral regimes

35) Anthony Cardesman, "The Lessons of the Iraq War: Executive Summary," July 21 (2003).

36) Bush (2003d).

37) Benjamin Schwarz, "Exporting the Myth of a Liberal America," World Policy Journal 15-3, pp. 69-77. 
and its nation-building projects have failed. ${ }^{38)}$ The dichotomy also casts aside a vast area of "gray" between modernity and tradition, a zone of "borrowing, indigenization, localization all terms meant to suggest a dynamic of cultural amalgamation and accommodation." 39 ) And, the dichotomy is a gross distortion of liberalism as monolithic entity. Liberalism is premised upon multiple principles such as political equality and self-determination, both of which combined would and have produced a wide set of various governance systems. ${ }^{40}$ )

Reagan once embodied these morally stylized scripts of modernity, which have been revived by the end of the Cold War and have found their way to America's official national security strategy and guided Bush's war on terror. As Lafeber succinctly formulates, "American exceptionalism plus the nature of power equals the efficacy of its unilateralism .41) The Cold War' end has ushered in not America's unipolar moment but its unipolar era, recalls Krauthamer who coined the term - the unipolar moment. Transforming a calculus of power into a question of morality, Krauthamer maintains that the 9-11 terrorists attacks only "heightened the asymmetry" but that posed a moral question in the unipolar era: "who will define the hegemon's ends?" Krauthamer takes the Cold War's end as a historical vindication of Reagan's moral certitude in America's universal values: his answer is that only America should define its foreign policy goals. ${ }^{42)}$

This logic elevates unilateralism from a means of American foreign policy into the latter's end. Then multilateralism comes to be denigrated as a moral ineptitude against the cause of both America and the whole world. For the curbing of American sovereignty leads to the diminishing of American power to materialize its foreign policy goals identical to the cause of the whole world. As Nye correctly points out, the moralizing of unilateralism is sure to cause problems in America's relations with other countries and international regimes. Moreover, the pluralist nature of the American democracy contradicts America's unilateral pursuit of moral goals, and thus American unilateralism as a moral end might undermine the very domestic support for American foreign policy-what Nye calls

38) Douglas Porch, "Occupational Hazards: Myths of 1945 and U.S. Iraq Policy," The National Interest 72, pp. 35-47; Irene I. Gendzier, "Invisible by Design: U.S. Policy in the Middle East," Diplomatic History 26-4(2002), pp. 593-618; Salim Yaqub, "Imperious Doctrines: U.S.-Arab Relations from Dwight D. Eisenhower to George W. Bush," Diplomatic History 26-4(2002), pp. 571-591; Michael E. Latham, Modernization as Ideology: American Social Science and Nation-Building in the Kennedy Era (Chapel Hill: University of North Carolina Press, 2000).

39) M. H. Hunt, "In the Wake of September 11: The Clash of What?" in J. Meyerowitz (ed.), History and September 11th (Philadelphia: Temple University Press, 2002), p. 11.

40) Edwards Rhodes, "The Imperial Logic of Bush's Liberal Agenda," Survival 45-1, pp. 131-154; Jededia Purdy, "Liberal Empire: Assessing the Arguments," Ethics \& International Affairs 17-2, pp. 35-47; Robert Latham, The Liberal Moment: Security and the Making of Postwar International Order (New York: Columbia University Press, 1997).

41) Walter Fafeber, "The Bush Doctrine," Diplomatic History 26-4(2002), p. 549.

42) Charles Krauthammer, "The Unipolar Moment Revisited," The National Interest 70, pp.5-17; Wolfowitz, "Remembering the Future," The National Interest 59(2000), pp. 35-45; Tony Smith, America's Mission: The United States and the Worldwide Struggle for Democracy in the Twentieth Century (Princeton: Princeton University Press, 1994). 
"imperial under-stretch."43)

A metamorphosis of power calculation into moral certitude is conspicuous in Bush's national security strategy. In its preface, Bush proclaims that the cold war's end vindicates the American way as the only way of human progress: "The great struggles of the twentieth century between liberty and totalitarian ended with a decisive victory for the forces of freedom - and a single sustainable model for national success: freedom, democracy, and free enterprise." Once grafted onto a script of moral certitude, the "certainty of surprise" changes the concept of American security and infinitely expands the spatial and time dimensions of American security. What should be protected includes not just American's material interests but also its values - "non-negotiable demands of human dignity."44) As such, the spatial boundaries of American security are not territorial but "the fault-lines within societies" between modemity and tradition, civilization and barbarism, and the American way and the un-American way. ${ }^{45)}$

America's "gravest danger" is located "at the cross roads of radicalism and technology." The 9-11 terrorist attacks evidenced the "certainty of surprise" and the spread of civilization - modernity, globalization, westernization and the American way of life - is destined to produce radicalism. Combined together, the sure existence and "evil" intention of America's enemies and their acquisition of potentially catastrophic weapons dictate an indefinite expansion of the time dimension of security threats: "We must adapt the concept of imminent threat to the capabilities and objectives of today's adversaries." ${ }^{46)}$ The only defense against such threat is offense, and which blurs the line between preemption and prevention completely. Preemption needs an imminent threat in a traditional sense such as enemy's mobilization; a new American definition of imminent threat extends far into the future.47) As such, the Iraq campaign is a preventive war, not a preemptive war. ${ }^{48)}$ On the other hand, the best offense is to eradicate radicalism by building democracy all over the world. This needs help from great powers. But, the Bush doctrine does not embrace the traditional power politics that relegates morality to the realm of convenience. Rather the Bush doctrine pursues "a balance of power favoring freedom."49)

In the sense that political equality among states is denied, the Bush doctrine is an illiberal liberalism or imperial liberalism. ${ }^{50)}$ The Bush doctrine builds on a hierarchy of

43) Nye(2003); see also G. John Ikenberry, “America's Imperial Ambition," Foreign Affairs 81-5, pp. 44-60.

44) The White House(2002), p. iv, 4.

45) P. Zelikow, "The Transformation of National Security: Five Redefinitions," The National Interest 71, pp. 17-28.

46) The White House(2002), p. v, 15.

47) Byers(2003); "Adam Roberts, Law and the Use of Force After Iraq," Survival 45-2(2003), pp. 31-56.

48) Richard Betts, "Striking First: A History of Thankfully Lost Opportunities," Ethics \& International Affairs 17-3(2003), pp. 17-24.

49) The White House(2002), p. v.

50) Rhodes(2003); Purdy(2003). 
morality or modernity/civilization among states, and accordingly imposes responsibilities on each state. Bush's national security strategy coins the term of "sovereign responsibilities" and Bush's national strategy for combating terrorism sets out a hierarchy or "caste" of states in terms of cooperation with war on terrorism: states willing and able to cooperate; states unable but willing to cooperate; states reluctant to cooperate; and states unwilling to cooperate. ${ }^{51)}$ In the world of the Bush doctrine, sovereignty is no longer a "blank check" Sovereignty is contingent upon states' responsibilities in fighting against terrorists, nonproliferation of weapons of mass destruction and regional stability, and intervention in failed states and regime changes.52)

\section{Conclusion: Mission Impossible?}

It is too early to tell the whole story of the Iraq campaign, not to mention America's indefinite war on terror. Nonetheless, the Bush doctrine seems to set up an exorbitant goal for America's security by moralizing the very concept of security and extending too much the spatial and time dimensions of security. Once American values elevated as the very core of security interests and America's security threats as lying at the "intersection of radicalism and technology," America's security could not be secured unless the whole world would be Americanized.

A world subject to American sovereignty and moral certitude is a dream, given that sovereignty, despite its much compromised history and hypocritical nature, has persisted as the organizing principle of the intemational system. ${ }^{53)}$ Even if all the radicalism would be wiped out, such a world would not be Bush's "Garden of Eden" for American exceptionalism. For nation-building requires much more than the "Shock and Awe" of the American military prowess and, moreover, liberalism itself means the right to dissent. After the fall of Baghdad, dissents and criticism of Bush's reconstruction of Iraq have abounded on the American, international, and Iraq fronts. For instance, Bush's September 2003 U.N. address that called for international help for the reconstruction of Iraq was met by wide spread criticism of American unilateralism. Sure, the Bush administration garnered additional $\$ 87$ billion from Congress, but not without heated domestic debates - the signs of "imperial under-stretch" - and criticism that multilateralism still matters and that the Bush administration has failed to secure America from the threats of terrorism and weapons of mass destruction. 54) Though the Bush administration boosted American morale by capturing Sadam Hussein in December 13, 2003, the Americans came to have Christmas

51) The White House, National Strategy for Combating Terrorism (2003), p.12.

52) Richard Haass, "Sovereignty: Existing Rights, Evolving Responsibilities," January 14 (2003).

53) Daniel Philpott, "Usurping the Sovereignty of Sovereignty?" World Politics 53-2 (2001), pp. 297-324.

54) Shashi Tharoot, "Why America Still Needs the United Nations," Foreign Affairs 82-5, pp. 67-80. 
of an orange terrorist attack warning; with Baghdad still enflamed, the Iraqis themselves are divided on the ways and schedules for a new democratic Iraq .55)

55) Edward Wong, "Sunnis in Iraq Form Own Political Council," The New York Times December 26 (2003). 


\section{References}

Anderson, Perry, "Force and Consent." New Left Review 17(2002).

Byers, Michael, "Letting the Exception Prove the Rule," Ethics \& International Affairs 17-1(2003).

Beard, Jack M., "America's New War on Terror: The Case for Self-Defense Under International Law,"

Harvard Journal of Law and Public Policy 25-2(2002).

Bearden, Milton, "Afghanistan, Graveyard of Empires," Foreign Affairs 80 6(2001).

Betts, Richard K., "The New Threat of Mass Destruction," Foreign Affairs 77-1(1998).

, "The Soft Underbelly of American Primacy: Tactical Advantages of Terror," Political Science Quarterly 117-1(2002).

, "Striking First: A History of Thankfully Lost Opportunities," Ethics \& International Affairs 17-3(2003).

Boot, Max, "The New American Way of War," Foreign Affairs 82-4(2003).

Bush, George W. "Address to the Nation," September 11 www. whitehosue. gove/ news/ releases/ 2001/09/20010911-16.html (2001a).

, "Remarks by the President in Photo Opportunity with the National Security," September 12, www.whitehouse.gov/new/releases/2001/09/20010912-4.htm. (2001b)

, "Address to a Joint Session of Congress and the American People,". September 20, http://www.whitehouse.gov/news/releases/2001/09/20010920-8.html. (2001c)

, "We're Fighting to Win-And Win We Will," December 7,

http://www.whitehouse.gov/news/releases/2001/12/20011207.html. (2001d)

, "State of Union Address," January 28,

http://www. whitehouse.gov/news/releases/2002/01/20020129-11.html. (2002a)

, "President Bush Delivers Graduation Speech at West Point," June 1, http://www. whitehouse.gov/news/releases/2002/06/20020601-3.html. (2002b)

"President Discusses the Future of Iraq," February 26,

http://www. whitehouse.gov/news/releases/2003/02/20030226-11.html. (2003a)

, "President George Bush Discusses Iraq in National Press Conference," March 6,

http://www.whitehouse.gov/news/releases/2003/03/20030306-8.html. (2003b)

, "President Bush Announces Major Combat Operations in Iraq Have Ended," May 1, http://www.whitehouse.gov/news/releases/2003/05/iraq/20030501-1.html. (2003c)

, "President Addresses the Nation," September 7.

http://www. whitehouse.gov/news/releases/2003/09/20030907-1.html. (2003d)

, "Text: Bush on Democracy in the Middle East," November 7, The New York Times (2003e).

Carter, Ashton B., "The Architecture of Government in the Face of Terrorism," International Security 26-3(2001/2002).

Carter, Ashton, and William Perry, Preventive Defense: A New Security Strategy for America. (Washington, D.C.: Brooking Institution Press), 1999.

Cordesman, Anthony H. "The Lesson of the Iraq War: Executive Summary," July 21, http://www.csis.org/irg_instantlesson_exec.pdf. (2003)

Crawford, Neta C., "Just War Thoery and the U.S. Counterterror War," Perspectives on Politics $1-1(2003)$. 
Feith, Douglas J. "Strategy and the Idea of Freedom." November 24.

http://www.defenselink. mil/speeches/2003/sp20031124-0703.html. (2003).

Flynn, Stephen E., "America the Vulnerable," Foreign Affairs 81-1(2002).

Gaddis, J.Lewis, "A Grand Strategy". Foreign Policy 133(2002).

Gehring, Verna V., ed. War After September 11 (New York: Rowman and Littlefield), 2003.

Gendzier, Irene I., "Invisible by Design: U.S. Policy in the Middle East," Diplomatic History 26 $-4(2002)$.

Haase, Richard, "Sovereignty: Existing Rights, Evolving Responsibilities," January 14. http://www.state.gov/s/rem/2003.1668pf.htm. (2003).

Heymann, Philip B., "Dealing with Terrorism: An Overview," International Security 26 $-3(2001 / 2002)$.

Hunt, M.H. "In the Wake of September 11: The Clash of What?" in Meyerowitz, J. (ed.) History and September $11^{\text {th }}$, (Philadelphia: Temple University Press), 2003.

Ikenberry, G. John, "America's Imperial Ambition," Foreign Affairs 81-5(2002).

Kurth, James, "America's Grand Strategy: A Pattern of History," The National Interest 43(1996).

Krauthammer, Charles, "The Unipolar Moment Revisited," The National Interest 70(2002/2003).

Lafeber, Walter, "The Bush Doctrine," Diplomatic History 26-4(2002).

Latham, Michael E., Modernization as Ideology: American Social Science and "Nation-Building" in the Kennedy Era, (Chapel Hill: University of North Carolina Press), 2000.

Latham, Robert, The Liberal Moment: Modernity, Security and the Making of Postwar International Order, (New York: Columbia University Press), 1997.

Luban, David, "The War on Terrorism and the End of Human Rights," in Gehring (ed.), War after September 11, (New York: Rowman \& Littlefield), 2003.

Mueller, John, "Harbinger or Aberration? A 9/11 Provocation," The National Interest 69(2002).

Nye, Joseph S., "U.S. Power and Strategy After Iraq," Foreign Affairs 82-4(2003).

Philpott, Daniel, "Usurping the Sovereignty of Sovereignty?" World Politics 53-2(2001).

Porch, Douglas, "Occupational Hazards: Myths of 1945 and U.S. Iraq Policy," The National Interest 72(2003)

Purdy, Jededia, "Liberal Empire: Assessing the Arguments," Ethics \& International Affairs 17 2(2003).

Rivkin, David R., and Lee A. Casey, "Leashing the Dogs of war," The National Interest 73 (2003).

Rhodes, Edwards, "The Imperial Logic of Bush's Liberal Agenda," Survival 45-1(2003).

Roberts, Adam, "Counter-terrorism, Armed Force and the Laws of War," Survival 44 1(2002). , "Law and the Use of Force After Iraq," Survival 45-2(2003).

Rumsfeld, Donald H., "A New Kind of War," The New York Times September 27 (2001). , "Transforming the Military," Foreign Affairs 81-3(2002).

Schwarz, Benjamin, "Exporting the Myth of a Liberal America," World Policy Journal 15 3(1998).

Smith, Tony, America's Mission: The United States and the Worldwide Struggle for Democracy in the Twentieth Century, (Princeton: Princeton University Press), 1994.

Tharoot, Shashi., "Why America Still Needs the United Nations," Foreign Affairs 82 5(2003).

The United States Commission on National Security/21 ${ }^{\text {st }}$ Century, New World Coming: American Security in the 2lst Century, 1999.

Wallerstein, Immanuel, "The Eagle Has Crash Landed," Foreign Policyl31 (2002).

The White House, The National Security Strategy of the United States of America, 2002. , National Strategy for Combating Terrorism. February 12, 2003. 
Wolfowitz, Paul, "Remembering the Future," The National Interest 59(2000). , Prepared Testimony: "Building a Military for the $21^{\text {st" }}$ Century" to the Senate Armed Services Committee. October 4, 2001. "Winning the Battle of Ideas: Another Front in the War on Terror," October 30. http://www.defenselink mil/speeches/2003/sp20031030-despsecdef0642.html. (2003).

Wong, Edward, "Sunnis in Iraq Form Own Political Council," The New York Times, December 26, 2003.

Yaqub, Salim, "Imperious Doctrines: U.S.-Arab Relations from Dwight D. Eisenhower to George W. Bush," Diplomatic History 26-4(2002).

Zelikow, P., "The Transformation of National Security: Five Redefinitions," The National Interest 71(2002). 